\title{
Law, social capital and tourism at Peneda-Gerês: An exploratory analysis of the leadership and decision-making processes
}

\author{
Direito, capital social e turismo na Peneda-Gerês: Uma análise \\ exploratória dos processos de liderança e tomada de decisão
}

\author{
Tiago Borlido \\ Universitat de Girona, Girona, Spain \\ tiago.borlido@gmail.com
}

\begin{abstract}
The following article seeks to explore the three-way relationship between law, social capital and tourism development through the analysis of the leadership and decision-making processes established by law in the Peneda-Gerês National Park, in Portugal. Since social capital is a determining element for the development of a sustainable tourism development model and law is accepted as a form of social capital, law was found to be of enormous importance for the implementation of an integrated rural tourism model in the national park area. The main conclusion extracted was that there are severe debilities in the leadership and decision-making processes, which in turn constituted serious hindrances to sustainable tourism development.
\end{abstract}

Keywords: social capital; law; tourism; leadership; decision-making; Peneda-Gerês National Park.

\section{Resumo}

\begin{abstract}
O seguinte trabalho explora a relação triangular entre Direito, capital social e desenvolvimento turístico através da análise dos processos de liderança e tomada de decisão estabelecidos por lei no Parque Nacional da Peneda-Gerês (Portugal). Sendo o capital social um elemento determinante para o desenvolvimento de um modelo de desenvolvimento turístico sustentável e a lei considerada uma forma de capital social, o Direito foi considerado como de enorme importância para a implementação de um modelo de turismo rural integrado na área do parque nacional. Concluiu-se que existem graves debilidades nos processos de liderança e tomada de decisão, que consequentemente constituem graves obstáculos ao desenvolvimento turístico sustentável.
\end{abstract}

Palavras-chave: capital social; direito; turismo; liderança; tomada de decisão; Parque Nacional da Peneda-Gerês.

\section{Introduction}

This article appears as part of a wider research context, which seeks to evaluate the social capital levels of a settlement in the Peneda-Gerês National Park (specifically, Lindoso) and how these impact, and are impacted by, tourism development. Although research on the theme is still in an incipient phase, the interest in the relationship between social capital and tourism has been growing in recent years, with several authors analyzing the theme (Bennett, Lemelin, Koster \& Budke, 2012; Fernandes, 2009; Gibson et al., 2014; Mbaiwa \& Stronza, 2010; McGehee, Lee, O’Bannon \& Perdue, 2010; Park, Lee, Choi \& Yoon, 2012; Zahra \& McGehee, 2013; Zhao, Ritchie \& Echtner, 2011).

Dos Algarves: A Multidisciplinary e-Journal, 28 - 2016. ISBN 2182-5580 ๑ ESGHT-University of the Algarve, Portugal.

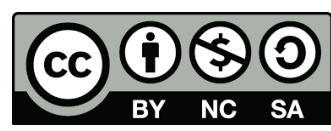

To cite this article: Borlido, T. (2016). Law, social capital and tourism at Peneda-Gerês: An exploratory analysis of the leadership and decision-making processes. Dos Algarves: A Multidisciplinary e-Journal, 28, 29-44. doi: 10.18089/DAMeJ.2016.28.3 
Research on social capital, on the other hand, has been prolific ever since Putnam popularized the concept with his magnum opus "Bowling Alone" (Field, 2008). Social capital, identified as the "missing link" in development, has been proposed as a determining element in domains as varied as human capital creation, sustainable development, economic growth, democracy, reduction of poverty or environmental sustainability (Coleman, 2000; Fernandes, 2009; Jones, 2005; Park, Lee, Choi \& Yoon, 2012; Putnam, Leonardi \& Nanetti, 1993).

While investigating such matters, an interest arose in what impacts the law would have in this theme, leading to the development of this article. Although law is, as will be discussed further below, inextricable from the notion of social capital, literature that connect the two concepts is very scarce (Coleman (1988) is the only noteworthy exception, although Ostrom (2000) and Bain \& Hicks (cited by Krishna \& Shrader, 2000) also briefly mention law in their work on social capital), and literature that connects these two fields with tourism is practically inexistent.

This article sought, then, to explore this three-way relationship through the analysis of a specific study case: the leadership and decision-making processes in the Peneda-Gerês National Park, a touristic destination of importance in Northern Portugal (Fernandes, 2009), in preparation for the empirical work that was to be done. Within this wide objective, two specific objectives were identified: to analyze how law, as a form of social capital impacted on tourism development on the Peneda-Gerês National Park; and to identify proposals regarding the improvement of the existing situation.

In the following two sections, a literature review that explains the connection between these three fields is presented, with the importance of social capital within sustainable tourism explained and the idea of law as a form of social capital developed. While the third section explains the methodology that was used in this work, the fourth introduces the case study, exploring how law influences social capital and tourism development in the Peneda-Gerês National Park. The last section summarizes the main conclusions extracted and presents possible policy proposals.

\section{Rural tourism and social capital}

\subsection{Overcoming the rural challenge: the role of tourism development}

Although the definition of rural area has been subject of discussion, the general characteristics that differentiate it from the urban area are, as stated by Cavaco (2004), a lower population density and a higher relative importance of agriculture in the economy and society.

These areas possess certain characteristics that create hindrances to the economic development which are specific to the rural reality. The economic development process is severely strained by the lack of local agents - needed to kick-start the economic development process - caused by the decrease and aging of the population (Galvão \& Devy-Vareta, 2010; Silva, 2007; Terres, Nisini \& Anguiano, 2013). Small scale agriculture, of great importance in the economy and society, has lost its economic viability, and the low levels of education of the rural population, associated with the lack of opportunities to increase them (due to the inexistence of knowledge centres), mean there are few opportunities for the inhabitants of these areas to find employment in other areas (Cavaco, 2004; Silva, 2007; Terres et al., 2013). The situation is aggravated by the weak business and 
institutional structure, low attractiveness for investors and infrastructure and service deficit, all characteristic of rural areas (Pato, Breda, Cunha \& Kastenholz, 2014; Silva, 2007). This conjuncture accelerates the rural exodus process, consequently generating a loss of self-esteem and sense of belonging in the population that is left behind and an identity crisis at the local level Cavaco (2004).

The picture drawn here gives a general idea of the serious challenges that rural areas face. Nevertheless, rural areas also possess certain features which serve as attractors for tourists, turning these territories into emerging tourist destinations (Galvão \& Devy-Vareta, 2010; McIntyre, Hetherington \& Inskeep, 1993). Based on these resources, tourism can trigger a process of revitalization of rural areas (Breda, Costa \& Costa, 2006; Fernandes, 2009; McIntyre et al., 1993).

This sector is of great importance for the development of rural areas due to the multiplier effect generated by tourism (Kastenholz \& Sparrer, 2009). Tourism can boost economic development, generating employment, additional income and economic expansion and creating infrastructure and equipment useful to the inhabitants of rural territories (McIntyre et al., 1993; Negi, 1990). It can also contribute to the conservation of cultural and natural heritage and to the increase of the population's quality of life, helping to retain the residents as a result (Kastenholz \& Sparrer, 2009; McIntyre et al., 1993; Page \& Getz, 1997).

However, the implementation of rural tourism models that exclude the residents and that bring reduced benefits to the inhabitants means this scenario does not occur in many cases (Fernandes, 2009; Kastenholz \& Sparrer, 2009; Park et al., 2012; Ribeiro \& Marques, 2002). In this context, the concept of integrated rural tourism presented by Saxena, Clark, Oliver and Ilbery (2007) is of great importance. Integrated rural tourism refers to "tourism explicitly linked to the economic, social, cultural, natural and human structures of the localities in which it takes place" (idem: 347 ). It is a model that aims for a sustainable tourism development that brings long term benefits for the population, grounded on the construction of formal and informal networks that enhance coordination and integration on a local level (idem).

These kind of models, defenders of an endogenous approach that implies the participation and empowerment of the population and supported by an organizational structure that facilitates community coordination, has obtained an increasing popularity among tourism academics (Fernandes, 2009). Although the popularity of such models is a relatively recent phenomenon, the importance of social networks and relationships for general economic development is not a recent notion: in fact, these ideas can be inserted in the concept of social capital, popularised by Robert Putnam in the 1990s (Fernandes, 2009; Field, 2008), and its importance for tourism development has been shown by authors such as Park et al. (2012) and Rebelo (2012).

\subsection{Social capital}

The concept of social capital was put forward in the beginning of the $20^{\text {th }}$ century by Hanifan (1916) and has since been the object of increasing interest, especially since Robert Putnam's work received widespread attention in the 1990 s.

Bourdieu, Coleman and Putnam have been recognized as the most relevant authors in social capital literature (Field, 2008). Bourdieu offers one the first systematic contemporary 
analyses of the concept, defining it as the sum of actual or potential resources related with the possession of a durable network of more or less institutionalized relationships of mutual acquaintance and recognition (Bourdieu, 1980; Portes, 1998). Nonetheless, it is Putnam's work that has been more publicized (Field, 2008). This author presents a significantly distinct definition for capital social, presenting it as the "(...) features of social organization such as networks, norms, and social trust that facilitate coordination and cooperation for mutual benefit" (Putnam, 1995: 2).

Coleman (2000a, 2000b), on the other hand, defends that social capital is not a singular entity, but a series of different entities that share two common elements: all are constituted by some aspect of social structures, and all facilitate certain actions by actors within those structures. Coleman, like Bourdieu, tends to approach social capital from the individual's point of view, while Putnam also approaches that of the group's (Field, 2008).

Although views on the concept differ, the core idea of social capital is, as Jones (2005: 306) postulates, "that social networks have value, as interaction and connections develop shared norms, trust, and reciprocity that in turn foster cooperation to achieve common ends". Social capital would refer, therefore, "to the degree of connectedness and the quality and quantity of social relations in a given population or the social relations that lead to constructive outcomes for a group" (Jones, 2005: 306, citing Bankston \& Zhou, 2002; Ecclestone \& Field, 2003; Harpham, Grant \& Thomas, 2002). The great majority of authors concurs that social capital is determinant in the generation of various positive externalities (Coleman, 2000; Fernandes, 2009; Jones, 2005; Park et al., 2012; Putnam et al., 1993).

An element often omitted is the fact that social capital does not always have positive effects; in fact, social capital can contribute significantly to cases of social exclusion and inequity (Arrow, 2000; Field, 2008; Putnam, 2000). Berman (1997) exemplifies this with the case of the choral societies and bird-watching societies in inter-war Germany, which served to deepen the country's social divisions, hiving their memberships off each other and creating jealous and competitive entities.

Uphoff (2000) and Krishna and Shrader (2000) distinguish between two forms of social capital: the cognitive/structural distinction. Cognitive social capital refers to values (such as trust, solidarity or reciprocity), to social norms, to behaviour and to attitudes; structural social capital, on the other hand, refers to the organizational structure, to the decisionmaking and leadership processes and to practices of collective action and responsibility. According to these authors, while cognitive factors create a predisposition towards mutually beneficial collective action, structural elements facilitate such action (Krishna \& Shrader, 2000; Uphoff, 2000). Law, as will be discussed further below, falls into the structural category of social capital (Bain \& Hicks, cited by Krishna \& Shrader, 2000).

These elements, despite their differences, are interdependent, since one form of social capital contributes to the development of the other. Both affect behaviour through expectations and both are reinforced by culture, Zeitgeist and other influences (Uphoff, 2000).

\subsection{Law: A form of social capital}

This analysis of the role law plays within the theme presented in the previous section begins with one question: What is law? Several opinions regarding the matter can be found: according to Hoebel (1954: 28) a social norm becomes law when " its neglect or infraction is 
regularly met, in threat or in fact, by the application of physical force by an individual or group possessing the socially recognized privilege of so acting"; Reale (2009) states that law can be understood, simply stated, as a set of obligatory rules that guarantee life in society by establishing limits to the action of each one of its members; the Collins Dictionary (2016) defines it as "a rule or set of rules, enforceable by the courts, regulating the government of a state, the relationship between the organs of government and the subjects of the state, and the relationship or conduct of subjects towards each other".

Like the examples presented, many definitions for "law" incorporate the idea that it regulates social relationships. If, as was discussed earlier, social capital is composed by social relationships and social structures originating from those social relationships it seems, therefore, evident that law has important implications for social capital theory. As Luhmann (1983) mentioned in his seminal work "A Sociological Theory of Law", all human coexistence is directly or indirectly affected by law.

The American sociologist James Coleman emphasizes the importance of law (more precisely, of legal allocation of rights) in the creation of social capital; as he exemplifies, if an entrepreneur does not have property rights to both the product he produces and the process by which it is produced, he does not have the motivation to create an organization that can help turn that product into reality, generating a lack of investment in social capital (Coleman, 1988).

Notwithstanding, to say that the importance of law for social capital consists in merely affecting its creation and destruction is to adopt a simplistic view of the complexity of this relation. Considering, on the one hand, the variety of authors (such as the above-mentioned Reale and Hoebel) that define law as a set of social norms or rules and, on the other, the abundance of conceptualizations of social capital (such as the ones put forward by Putnam or Jones, mentioned in the previous section) that specifically indicate social norms as a form of social capital, it can be concluded that all law is a form of social capital. Effectively, laws are social norms (cognitive social capital) that were "structuralized" through the imputation of juridical force.

Such a conclusion is sustained by some authors, with several authors supporting an approach to the concept of social capital that includes the socio-political environment in which social relationships and structures are inserted (including formalized structures and relations such as governments, judicial systems or the law) (Serageldin \& Grootaert, 2000). Bain and Hicks (cited by Krishna \& Shrader, 2000) and Ostrom (2000) are good examples.

The law, therefore, is a component of social capital of great importance, and plays a very important part in the social dynamics of any community or society. Although social capital is described by several authors as essential to sustainable tourism development, current tourism research has failed to connect these three fields and as a result law has often been overlooked in studies on social capital and tourism. This paper seeks to promote research towards the bridging of this gap.

\section{Methodology}

An exhaustive analysis of how legislation affects social capital levels in the Peneda-Gerês National Park and its relation with touristic development would, considering that all law is social capital, require an analysis of all current existing legislation in the territory associated 
with an empirical study. However, due to logistical and time restrictions an empirical study could not be conducted. Considering that an extensive analysis of all applicable legislation would also be prohibitively time consuming, an exploratory qualitative analysis of the leadership and decision-making processes was considered the most adequate methodological option.

The study consisted, on a first phase, of descriptive research on applicable legislation related with the above-mentioned processes. Descriptive research, as the name indicates, "[...] describes the state of affairs as it exists at present [... ]. It therefore does not go into the causes of the phenomenon or situation." (Vibhute \& Aynalem, 2009: 16). Such a methodology was considered the most adequate as a basis for the case study of the Peneda-Gerês National Park.

These legal documents were analysed following the principles of teleological interpretation, which refers to interpretation aimed at the explicitly or implicitly stated purpose of a legal norm expressed in the law or of the piece of legislation to which the interpreted norm belongs (Itzcovich, 2009; Wintr \& Koželuha, 2015). Such a methodology follows the ideas defended by the Portuguese Civil Code: "Interpretation of the law must not be limited to the letter of the law; it must instead reconstitute, from the texts, the legislative thought, taking into account the unity of the juridical system, the circumstances in which the law was created and the specific conditions of the time in which it is applied" (Código Civil, 2015: 12).

In a second phase, a documental analysis was conducted following a search for empirical evidence. Documental analysis is a method that restricts to documents, written or not, as a source of data collection. These documents constitute what is called primary sources (Marconi \& Lakatos, 2003). The documental sources found, namely previous empirical studies and statistical data, were then used to construct an outline of the impacts of the leadership and decision-making processes imposed by law on the park area.

\section{Portuguese law and the leadership and decision-making processes}

\subsection{The leadership process}

The leadership process is strongly affected by the 1976 Portuguese Republic's Constitution (Constituição da República Portuguesa, 1976), which institutes several administrative bodies that compose the core of the leadership process in the present case. According to the Constitution, there are several types of local authorities subordinated to the Government; first-level administrative divisions correspond to the autonomous regions in the islands and the administrative regions in the continent.

Autonomous regions have a set of extra powers, justified by their specific geographical, economic, social and cultural characteristics, as well as by their historical pretensions of autonomy. Two autonomous regions exist in Portugal, corresponding to the two archipelagos inside Portuguese territory: Madeira and Azores.

In the continent, administrative regions exercise, according to the Constitution, administrative supervision, albeit with significantly reduced powers. However, although they have been established in the Constitution since its creation in 1976, administrative regions were never implemented. Foreseeing this possibility, article 291 of the same document stipulates that, while these regions are not implemented, the district division 
should serve as substitute, with each district having a district assembly (deliberative body) and civil governor (executive body).

Nevertheless, the district system also lacks real execution. Although district assemblies are currently in function, the post of civil governor was eliminated with Resolution 13/2011, due to the growing reduction of its relevance and of the powers assigned to it, which converted the civil governor, according to the aforementioned resolution, in an obsolete institution. Decree-Law 114/2011 (Decreto-Lei n. ${ }^{\circ}$ 114/2011) transfers the powers that were still attributed to the civil governor to other entities in public administration, such as the municipalities or the PSP (police force), among others.

The executive power is thus effectively extinguished in the first-level of administration; the deliberative bodies (the district assemblies), however, are maintained. According to Law 36/2014 (article 5) (Lei n. ${ }^{\circ} 36 / 2014$ ), it is their competence to discuss and deliberate on questions related with the economic development of the district or with the common interest of its population, as well as to develop and approve its own by-laws.

The extinction of the post of civil governor created an institutional void at the first administrative level. The competences that should be assigned to this level are, in part, assumed by other entities: of these, the commissions for regional coordination and development (CCDRs), the inter-municipal communities and the metropolitan areas were considered the most relevant.

These last two relate to article 253 of the Portuguese Constitution, which established the possibility of establishment of associations or federations of municipalities. Such a possibility is regulated by Law 75/2013 (Lei n. ${ }^{\circ}$ 75/2013), which divides the Portuguese territory into 23 inter-municipal entities ( 21 inter-municipal communities and 2 metropolitan areas). These bodies' functions are mainly related with planning, coordination and support to development, although additional administrative functions may be delegated unto them by municipalities or national administrative entities (Lei n. ${ }^{\circ}$ 75/2013).

The CCDRs are institutions created by Decree-Law 104/2003 (Decreto-Lei n. ${ }^{\circ} 104 / 2003$ ) and that, according to the same decree, strive for the enhancement, monitoring and evaluation of the administrative decentralization process. They possess competences in regional planning and development, environment and biodiversity, nature conservation and territory management.

Second-level administrative divisions correspond, both in the islands and the mainland, to municipalities. These are constituted by two bodies (article 250 of the Constitution): a deliberative one (the municipal assembly) and an executive one (the municipal council). Like the administrative regions, municipalities have regulatory powers, in accordance with the Constitution and with the regulations emitted by authorities with supervisory power and administrative entities of superior level (article 241).

Municipalities are divided into freguesias, which are the third-level administrative divisions. Their inner functioning is similar to that of the municipalities: they also have a deliberative organ (the freguesia assembly, which may, in cases in which the freguesia has a reduced number of inhabitants, be substituted by the totality of voting citizens) and an executive organ (the freguesia council). Additionally, these organs can delegate administrative tasks unto the inhabitants of the areas which they supervise, as long as they do not imply the use of authority powers.

Freguesias can also opt to boost population participation in the political life through the constitution of resident organizations, which are subordinated to the freguesia 
assemblies and are enshrined in articles 263 to 365 of the Constitution. These are constituted by a resident assembly, composed by all residents within the organization's territorial delimitations (according to the census), and by a resident commission, elected by the assembly through secret vote. Such bodies may petition superior administrative bodies regarding matters which are of the residents' interest. Additionally, they participate, without right to vote and through designated representatives, in the freguesia assembly. The law or administrative organs of the freguesia may also delegate further tasks unto them.

The administrative structures established by the Constitutional text are, thus, explained. Although these bodies can be considered as the most determinant due to the great coercive power that they possess, other entities are implied in the leadership process; as Fernandes (2009, citing Silva, 1994) describes, in the relative isolation of the mountain villages in the Peneda-Gerês National Park, persons such as the village priest or the professor gain authority due to hierarchic delegation or local status. There are, therefore, various entities implied in the leadership process that do not have such an evident and direct connection to law as the administrative bodies do.

Nevertheless, another entity exists that is implicated in the leadership process and is regulated by national legislation: the administration of the national park. The Peneda-Gerês National Park was created by Decree $187 / 71$ (Decreto $n .^{\circ} 187 / 71$ ) as the first national park in the Portuguese continent. The same document gives the park administrative and financial autonomy, as well as legal capacity, and establishes its administrative organ: an administrative commission, which is assessed by a scientific commission and by a technical and advisory commission. The local administrations (more specifically, the municipal chambers) participate as members of the technical and advisory commission.

The park administration was integrated in the Institute for Nature and Forest Conservation's department of nature and forest conservation for the North of Portugal, created by Ordinance 353/2012 (Portaria n. ${ }^{\circ}$ 353/2012) with all park management assumed by the mentioned department (Deliberação n. ${ }^{\circ}$ 1599/2013). Since it has functions of territory management, associated with a territory management plan, it plays an important part of the leadership process.

\subsection{The decision-making process}

The decision-making process is also established by the Constitution, and is similar for all administrative levels: article 10 establishes that political power is exercised by the population through universal suffrage, which is egalitarian, secret and periodic. Articles 115 and 240 also allow the use of other tools such as referendums.

Political parties participate in the suffrage process, contributing to the organisation and expression of the people's will (article 10). All citizens above 18 years of age have the right to vote, except for the incapacities contemplated in the general law. The conversion of the votes for the local and national legislative bodies' elections is done by using the Hondt method of the highest average (articles 149 and 260), while in the president's case the candidate elected is the one that successfully obtains more than $50 \%$ of the total votes; if this is not achieved by any of the candidates on the first round, a second round takes place with only the two most voted candidates. 
At the local level, the population can also intervene in the decision-making process through the aforementioned resident organizations.

\section{The case of the Peneda-Gerês National Park (Portugal) and juridical implications}

\subsection{Introduction to the area under analysis}

The Peneda-Gerês National Park was founded in 1971, becoming the first area in Portugal to be classified as a protected area (Fernandes, Matoa \& Brysch, 2002; Instituto da Conservação da Natureza e das Florestas, n.d.). It occupies a total area of 69596 hectares, spread out over 22 freguesias in five municipalities (Arcos de Valdevez, Melgaço, Montalegre, Ponte da Barca e Terras de Bouro) of Northern Portugal (see Figure 1) (Instituto da Conservação da Natureza e das Florestas, n.d.). Agriculture and livestock are, historically and to this day, the main economic activities in the area (Fernandes, 2009).

Figure 1. Map of the Peneda-Gerês National Park

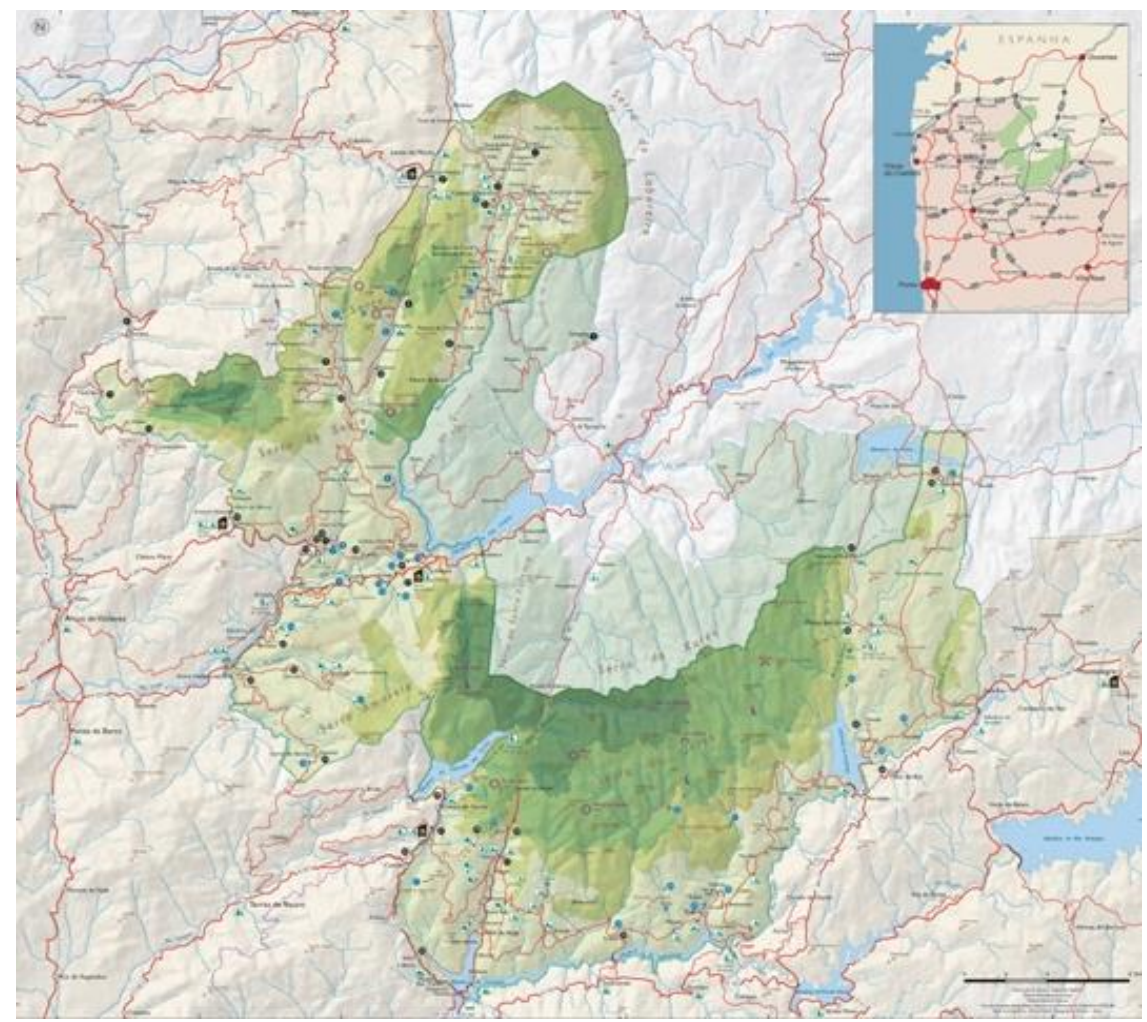

Source: Instituto da Conservação da Natureza e das Florestas, n.d.

The park is located in a highly mountainous area with a dense hydrographical network (which includes thermal springs) and a diverse fauna and flora. The park also has a rich built cultural heritage, encompassing pre-historic and roman archaeological sites, medieval monasteries and towns and a baroque sanctuary, as well as an intangible heritage of significant importance (Fernandes, 2009; Instituto da Conservação da Natureza e das Florestas, 2013).

These aspects are touristic resources of great importance and explain why tourism is an economic activity of importance in the area since the beginning of the $20^{\text {th }}$ century, in particular due to Vila do Gerês' thermal spa (Fernandes, 2009). Nevertheless, tourism grew 
considerably with the classification of the area as a national park (Fernandes et al., 2002). As can be verified in Figure 2, tourism levels have been growing in recent years, with the park receiving an average of about 66 thousand visitors to its visitor reception centres per year (between 2011 and 2014).

Figure 2. Visitors to visitor reception centres at the Peneda-Gerês National Park between 2011 and 2014

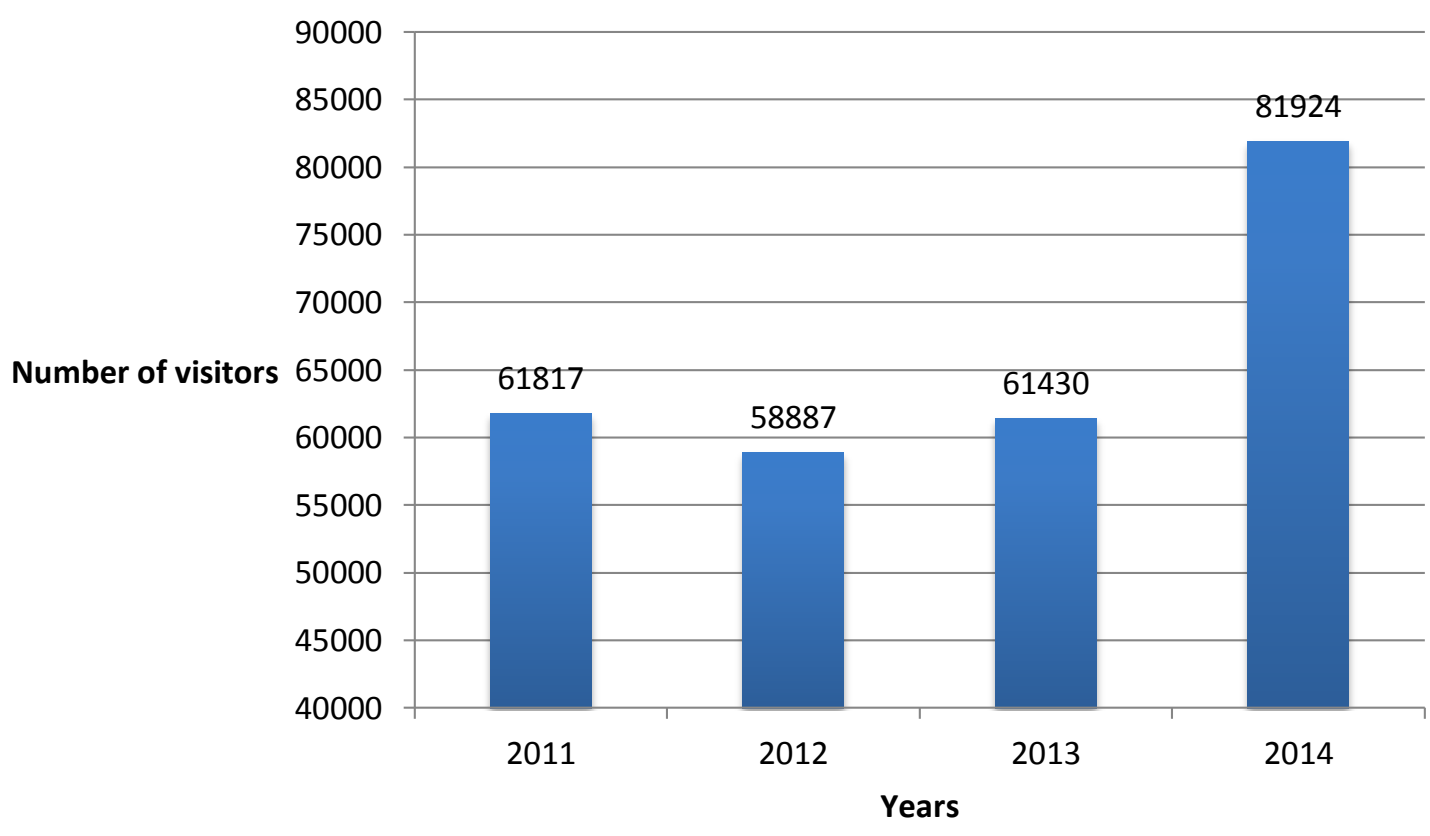

Source: Ferreira, 2016.

\subsection{Law, social capital and touristic development in the Peneda-Gerês National Park}

In the previous section, the influence of the law in the leadership and decision-making processes was explained. But how does the legislation impact day-to-day life on the specific case of the Peneda-Gerês National Park? What influence does this have in the tourism sector?

As already mentioned, the Peneda-Gerês National Park has always had significant amounts of tourism, which have increased since its designation as national park. Notwithstanding, community tourism planning is very scarce or poorly executed, due to the lack of experience and knowledge possessed by the members of local administrations in areas such as economic development or growth management; in fact, in many cases, the members of the freguesia councils are farmers with low education levels (Fernandes et al., 2002).

There is, furthermore, a history of conflict between the park's authorities and the local population, since the former did not bring the benefits expected by the park's communities. This is due, mostly, to flawed communication between the park's administration and the population; the latter's opinion is frequently ignored when tourism and conservation policy and strategy is created for the national park. For these reasons, regional organizations in the area tend to consider that tourism has brought more damage than benefits in the national park region (Fernandes et al., 2002). 
This scenario allows for a better comprehension of why the population in this area feels so excluded from the decision-making process (Fernandes, 2009). Additionally, apart from the elections, the inhabitants of the national park have little opportunity to participate in the decision-making process, as other mechanisms are rarely utilized. Referendums, for example, were only held on four occasions at the local level in Portugal (none of which was in any of the freguesias or municipalities that make up the Peneda-Gerês National Park) (Trincão, 2012).

Although this could be attributed to structural problems in the processes established by law, it should be noted that a significant part of the population either has no interest in participating in the decision-making process or is not preoccupied by the lack of participation because they feel that their opinion is not important (Fernandes, 2009). This issue is confirmed by the high levels of abstention in recent years' local elections (see Figure 3). This is, thus, the main challenge to solve for the promotion of the efficiency of the leadership and decision-making processes.

Figure 3. Percentage of abstainers in local elections for the Municipal Council in the municipalities of the Peneda-Gerês National Park in the elections between 2001 and 2013

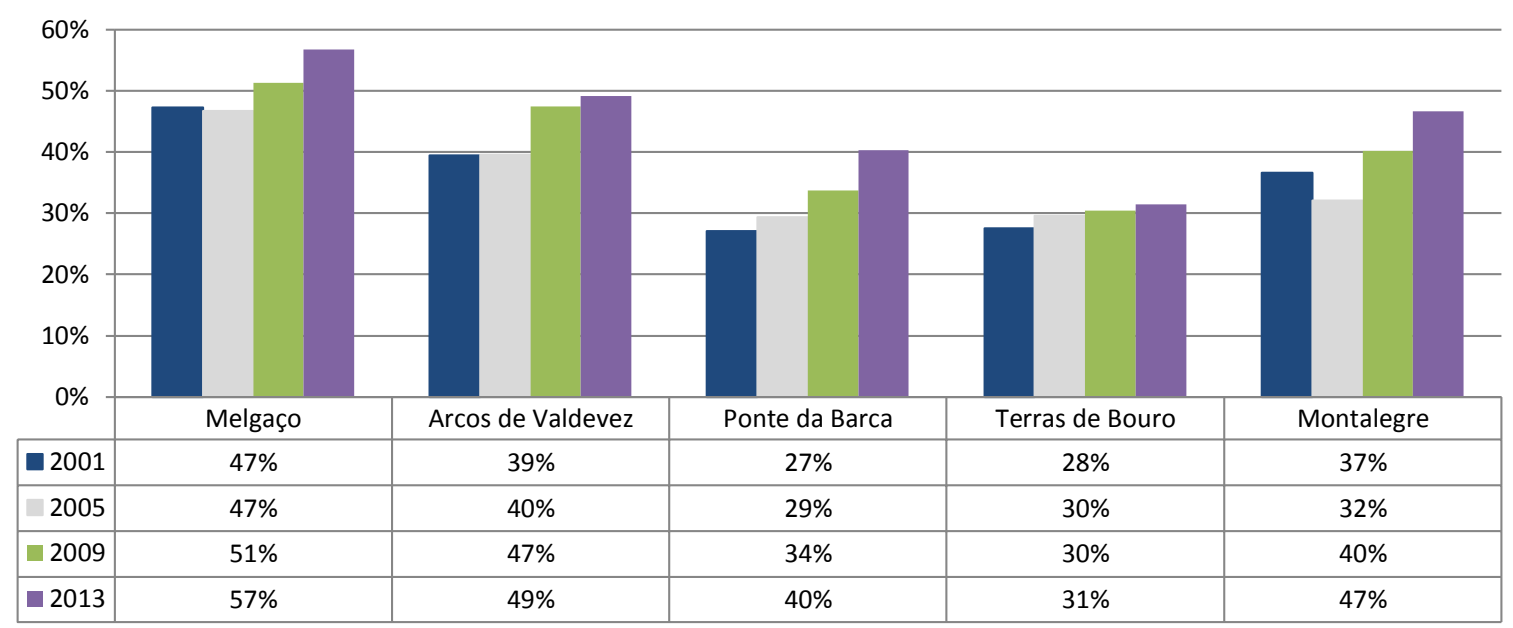

Source: Comissão Nacional de Eleições, 2013, 2009.

\section{Conclusions and proposals}

This article has sought to explore the role law plays in social capital levels in the PenedaGerês National Park and in the relation it establishes with touristic development. The starting point was an analysis of the role tourism plays in the sustainable development of rural areas. As low quality of life pushes rural populations out of their places of origin, tourism can have a key role in the revitalization of rural areas and in the inversion of this tendency.

Nevertheless, this only occurs when sustainable tourism development models are implemented, actively implicating the participation of the population through formal and informal networks that promote coordination and integration at the local level. In other 
words, tourism development models bring benefits to the population and the territory when they consider the importance of social capital.

The concept of social capital focuses on the idea that social networks and social structures have value, producing positive externalities. This concept, developed by several authors throughout the $20^{\text {th }}$ century has been considered by some authors as the "missing link" in development, and has been recognized as a decisive element in domains as varied as democracy, sustainability, poverty reduction or tourism.

Law plays in this context a role of great importance. In effect, law is a set of social norms to which juridical force was attributed; it is, therefore, a form of social capital. An exhaustive analysis of the role it plays in the Peneda-Gerês National Park's social capital would, hence, require an analysis of all current legislation in the territory. This article, however, chose to focus on how law affects two specific aspects of social capital: the leadership and decision-making processes. A brief analysis concluded that its influence is, in effect, of great importance.

The leadership process is mostly established by the Portuguese Constitution, which defines four administrative levels (the country, the autonomous/administrative regions, the municipalities and the freguesias), each with corresponding executive and deliberative organs. Since administrative regions were never implemented, although they have been included in the Constitution since its very beginning, these are substituted by the intermunicipal entities and commissions for regional coordination and development (CCDRs). These assume some of its competences but cannot completely eliminate the institutional void that exists at this administrative level. The decision-making process is also established by the Constitution, including the elective process by universal suffrage, as well as other tools such as the referendums.

An analysis of the day-to-day application of these processes in the Peneda-Gerês National Park evinces serious problems that affect its functioning, hindering the territory's sustainable touristic development:

1. An institutional void exists on the first administrative level;

2. Community planning is scarce, mostly due to lack of education by the individuals that occupy administration posts in the territory;

3. Communication flaws cause conflicts between the park's administration and the inhabitants;

4. The population feels they possess no influence in decision making, as elections are the only opportunity they have to participate in it;

5. The population is not interested in participating in the decision-making process.

Based on the problems identified and on the literature review, possible policy proposals to be implemented by regional and national administrations were identified to foster an integrated rural tourism model:

1. Acceleration of the implementation of administrative regions, so that citizen participation in political life can be furthered and the institutional void eliminated;

2. Promotion of actions of education in matters such as economic and touristic development or territory management for elected local officials, aiming for the improvement of their role as promoter of the territory's sustainable development; 
3. Raising local administrative bodies' awareness of the variety of decision-making mechanisms (other than elections) available to deepen the population's participation in the political life and promotion of its use;

4. Development of a communication policy between the several administrative entities and between them and the local population, striving for the elimination of conflicts born out of communication flaws and for the enhancement of the population's participation in decision-making;

5. Development of a sustainable tourism development strategy for the Peneda-Gerês National Park area, from a community tourism perspective - as Fernandes (2009) had already proposed - aiming for a wider distribution of the benefits generated by tourism and for the promotion of the population's participation in decisionmaking;

6. Development of awareness campaigns that push the population towards a more active participation in political life.

The need for reforms in the functioning of leadership and decision-making processes is, thus, evident if integrated rural tourism development is to be achieved for Peneda-Gerês. Social capital plays an essential role here, as formal and informal networks are the foundation on which this new model must be erected; the author's hope is, therefore, that this concept is integrated in local development policies.

It is also the author's hope that this article may contribute to the fomentation of academic discussion on the role of the law in social capital theory, since, despite its deep intertwinement, the two concepts have received very little attention from the academic community. In effect, as was discussed before, any legal document is passible of analysis as a component of social capital, and therefore ample opportunities of research exist within this field. An especially interesting angle would be the analysis of legislation associated with organizational structure and its effects on the tourism sector.

\section{References}

Arrow, K.J. (2000). Observations on social capital. In P. Dasgupta \& I. Serageldin (Eds.), Social capital: A multifaceted perspective (pp. 3-5). Washington D.C.: The World Bank.

Bankston III, C. \& M. Zhou (2002). Social capital as process: The meanings and problems of a theoretical metaphor. Sociological Inquiry 72 (2), 285-317. doi: 10.1111/1475-682X.00017

Bennett, N., Lemelin, R.H., Koster, R. \& Budke, I. (2012). A capital assets framework for appraising and building capacity for tourism development in aboriginal protected area gateway communities. Tourism Management, 33 (4), 752-766. doi: 10.1016/j.tourman.2011.08.009

Berman, S. (1997). Civil society and political institutionalization. American Behavioral Scientist, 40 (5), 562-574. doi: 10.1177/0002764297040005003

Bourdieu, P. (1980). Le capital social: Notes provisoires. Actes de la Recherche en Sciences Sociales, 31 (1), 2-3.

Breda, Z., Costa, R. \& Costa, C. (2006). Do clusters and networks make small places beautiful? The case of Caramulo (Portugal). In L. Lazzeretti \& C.S. Petrillo (Eds.), Tourism, local systems and networking (pp. 67-82). Oxford: Elsevier.

Cavaco, C. (2004). Desafios de desenvolvimento rural: Notas de leitura. Finisterra, XXXIX (78), 99-112. Código Civil (2015). $7^{\text {th }}$ edition. Coimbra: Almedina.

Coleman, J.S. (1988). The creation and destruction of social capital: Implications for the law. Notre Dame Journal of Law, Ethics \& Public Policy, 3 (3), 375-404.

Coleman, J. S. (2000a). Foundations of social theory (3rd ed.). Cambridge, MA: The Belknap Press of Harvard University Press. 
Coleman, J.S. (2000b). Social capital in the creation of human capital. In P. Dasgupta \& I. Serageldin (Eds.), Social capital: A multifaceted perspective (pp. 13-39). Washington D.C.: The World Bank.

Collins Dictionary (2016). Definitions of law. Retrieved from http://www.collinsdictionary.com/dictionary/english/law

Comissão Nacional de Eleições (11 November 2009). Resultados eleitorais: Autárquicas. Retrieved from http://eleicoes.cne.pt/raster/index.cfm?dia=11\&mes=10\&ano=2009\&eleicao=af

Comissão Nacional de Eleições (29 December 2013). Eleições Autárquicas 2013: Eleição Autárquica Geral. Retrieved from http://www.cne.pt/content/eleicoes-autarquicas-2013

Constituição da República Portuguesa (2 April 1976) [Constitution of the Portuguese Republic].

Decreto n. ${ }^{\circ} 187 / 71$ de 8 de maio [Decree 187/71]. Diário da República: 1. ${ }^{a}$ série n. ${ }^{\circ} 108$ (pp. 657-661).

Decreto-Lei n. ${ }^{\circ} 104 / 2003$ de 23 de maio [Decree-Law 104/2003]. Diário da República: $1 .^{a}$ série-A n. 119 (pp. 3222-3229).

Decreto-Lei n. ${ }^{\circ} 114 / 2011$ de 30 de novembro [Decree-Law 114/2011]. Diário da República: 1 . $^{\mathrm{a}}$ série n. ${ }^{\circ} 230$ (pp. 5130-5186).

Deliberação n. ${ }^{\circ} 1599 / 2013$ de 21 de agosto [Deliberation 1599/2013]. Diário da República: $2 .^{a}$ série n. ${ }^{\circ}$ 160 (pp. 26274-26276).

Ecclestone, K., and J. Field (2003). Promoting social capital in a "risk society": A new approach to emancipatory learning or new moral authoritarianism? British Journal of Sociology of Education 24 (3), 267-282. doi: 10.1080/01425690301895

Fernandes, C. de O. (2009). Community engagement with local associations and in the development of tourism: A case study of residents of three parishes in the Peneda-Gerês National Park. (Unpublished Ph.D. thesis). University of Bournemouth, UK.

Fernandes, C. de O., Matos, O. \& Brysch, T. (2002). Heritage and cultural landscape interpretation and sustainable tourism development in remote rural areas: A case study in the Peneda-Gerês National Park. In N. Andrews, S. Flanagan \& J. Ruddy (Eds.), Tourism destination planning (pp. 65-85). Dublin: Dublin Institute of Technology.

Ferreira, J.M. da C. (2016). Acessibilidade no turismo ativo: Análise exploratória do Parque Nacional da Peneda-Gerês. (Unpublished Masters dissertation). Universidade de Coimbra, Portugal. Retrieved from https://estudogeral.sib.uc.pt/bitstream/10316/30809/2/Capa e Folha de Rosto.pdf

Field, J. (2008). Social capital. (2 $2^{\text {nd }}$ edition). Abingdon: Routledge.

Galvão, M.J. \& Devy-Vareta, N. (2010). A multifuncionalidade das paisagens rurais: Uma ferramenta para o desenvolvimento. Cadernos: Curso de Doutoramento em Geografia, 2 (pp. 61-86).

Gibson, H.J., Walker, M., Thapa, B., Kaplanidou, K., Geldenhuys, S. \& Coetzee, W. (2014). Psychic income and social capital among host nation residents: A pre-post analysis of the 2010 FIFA World Cup in South Africa. Tourism Management, 44, 113-122. doi: 10.1016/j.tourman.2013.12.013

Hanifan, L.J. (1916). The rural school community center. The Annals of the American Academy of Political and Social Science, 67, 130-138.

Harpham, T., E. Grant, and E. Thomas (2002). Measuring social capital within health surveys: Key issues. Health Policy and Planning 17 (1), 106-111. doi: 10.1093/heapol/17.1.106

Hoebel, E. A. (1954). The law of primitive man: A study in comparative legal dynamics. Cambridge, MA: Harvard University Press.

Instituto de Conservação da Natureza e Florestas. (2013). Parque Nacional da Peneda-Gerês. Retrieved from http://www.icnf.pt/portal/naturaclas/ap/resource/ap/pnpg/brochur2013

Instituto da Conservação da Natureza e das Florestas (n.d.). Áreas Protegidas: Parque Nacional da Peneda-Gerês: Classificação | Caracterização. Retrieved from http://www.icnf.pt/portal/ap/pnpg/class-carac

Itzcovich, G. (2009). The interpretation of Community Law by the European Court of Justice. German Law Journal, 10 (5), 537-560. doi: 10.2139/ssrn.1892093

Jones, S. (2005). Community-based ecotourism: The significance of social capital. Annals of Tourism Research, 32 (2), 303-324. doi: 10.1016/j.annals.2004.06.007

Kastenholz, E. \& Sparrer, M. (2009). Rural dimensions of the commercial home. In P. Lynch, A.J. McIntosh \& H. Tucker (Eds.), Commercial homes in tourism: An international perspective (pp. 138-150). Abingdon: Routledge.

Krishna, A. \& Shrader, E. (2000). Cross-culture measures of social capital: A tool and results from India and Panama (Working Paper No. 21). Social Capital Working Paper Series. Washington D.C.: The World Bank Social Development Department.

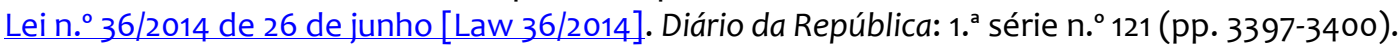

Lei n. ${ }^{\circ} 75 / 2013$ de 12 de setembro [Law 75/2013]. Diário da República: 1. ${ }^{a}$ série n. ${ }^{\circ} 176$ (pp. 5688-5724). 
Luhmann, N. (1983). Sociologia do direito (Vol. 1). Rio de Janeiro: Tempo Brasileiro.

Marconi, M. de A. \& Lakatos, E.M. (2003). Fundamentos de metodologia científica. ( $5^{\text {th }}$ edition). São Paulo: ATLAS.

Mbaiwa, J.E. \& Stronza, A.L. (2010). The effects of tourism development on rural livelihoods in the Okavango Delta, Botswana. Journal of Sustainable Tourism, 18 (5), 635-656. doi: $10.1080 / 09669581003653500$

McGehee, N.G., Lee, S., O’Bannon, T.L. \& Perdue, R.R. (2010). Tourism-related social capital and its relationship with other forms of capital: An exploratory study. Journal of Travel Research, 49 (4), 486-500. doi: 10.1177/0047287509349271

McIntyre, G., Hetherington, A. \& Inskeep, E. (1993). Sustainable tourism development: Guide for local planners. Madrid: World Tourism Organization.

Negi, J. (1990). Tourism development and resource conservation: An environmental, ecological, socioeconomic \& cultural approach to tourism in developing countries. New Delhi: Metropolitan.

Ostrom, E. (2000). Social capital: A fad or a fundamental concept? In P. Dasgupta \& I. Serageldin (Eds.), Social capital: A multifaceted perspective (pp. 172-214). Washington D.C.: The World Bank.

Page, S.J. \& Getz, D. (1997). The business of rural tourism: International perspectives. In S.J. Page \& D. Getz (Eds.), The business of rural tourism: International perspectives (pp. 3-37). London: International Thomson Business Press.

Park, D.-B., Lee, K.-W., Choi, H.-S. \& Yoon, Y. (2012). Factors influencing social capital in rural tourism communities in South Korea. Tourism Management, 33 (6), 1511-1520. doi : 10.1016/j.tourman.2012.02.005

Pato, L., Breda, Z., Cunha, C. \& Kastenholz, E. (2014). Experiência turística rural vivida e cocriada pelos agentes da oferta e de planeamento. In E. Kastenholz, C. Eusébio, E. Figueiredo, M.J. Carneiro \& J. Lima (Eds.), Reinventar o turismo rural em Portugal: Cocriação de experiências turísticas sustentáveis (pp. 107-124). Aveiro: UA Editora.

Portaria $n^{\circ} 353 / 2012$ de 31 de outubro [Ordinance 353/2012]. Diário da República I Série $n^{\circ} 211$ (pp. 6266-6269).

Portes, A. (1998). Social capital: Its origins and applications in modern sociology. Annual Review of Sociology, 24, 1-24. doi: 10.1146/annurev.soc.24.1.1

Putnam, R.D. (1995). Bowling alone: America's declining social capital. Journal of Democracy, 6 (1), 65-78. doi: 10.1353/jod.1995.0002

Putnam, R.D. (2000). Bowling alone: The collapse and revival of American community. New York: Simon \& Schuster.

Putnam, R.D., Leonardi, R. \& Nanetti, R.Y. (1993). Making democracy work: Civic traditions in modern Italy. Princeton, NJ: Princeton University Press.

Reale, M. (2009). Lições Preliminares de Direito. ( $27^{\text {th }}$ edition). São Paulo: Saraiva.

Rebelo, D.G.V. da S. (2012). The role of social relationships in the setting up and management of small tourism businesses in two Portuguese rural areas. (Unpublished Ph.D. thesis). University of Bournemouth, UK.

Resolução n 13/2011 de 30 de junho [Resolution 13/2011]. Diário da República II Série nº 124 (p. 27429).

Ribeiro, M. \& Marques, C. (2002). Rural tourism and the development of less favoured areas between rhetoric and practice. International Journal of Tourism Research, 4 (3), 211-220. doi: 10.1002/jtr.377

Saxena, G., Clark, G., Oliver, T. \& Ilbery, B. (2007). Conceptualizing integrated rural tourism. Tourism Geographies, 9 (4), 347-370. doi: 10.1080/14616680701647527

Serageldin, I. \& Grootaert, C. (2000). Defining social capital: An integrating view. In P. Dasgupta \& I. Serageldin (Eds.), Social capital: A multifaceted perspective (pp. 40-58). Washington D.C.: The World Bank.

Silva, R. (2007). Municípios e desenvolvimento local em regiões de baixa densidade. In Atas do III Congresso de Estudos Rurais - Agricultura Multifuncional, Desenvolvimento Rural e Políticas Públicas (pp. 20-21). Faro: Sociedade Portuguesa de Estudos Rurais \& Universidade do Algarve. Retrieved from http://sper.pt/oldsite/IIICER/Resumos/5_LivroDeResumos_3CER_Painel3.pdf

Terres, J.M., Nisini, L. \& Anguiano, E. (2013). Assessing the risk of farmland abandonment in the EU. [Reference Report EUR 25783 EN]. European Commission Joint Research Centre, Institute for Environment and Sustainability. Retrieved from http://ec.europa.eu/agriculture/externalstudies/2013/farmland-abandonment/fulltext_en.pdf

Trincão, A.M.M. (2012). Mecanismos de participaçãa política e a qualidade da democracia nos municípios portugueses (Unpublished Masters dissertation). Universidade do Minho, Portugal. 
Retrieved from http://repositorium.sdum.uminho.pt/bitstream/1822/23485/1/Tese _ Alexandra Maria Marinho Trinc\%C3\%A30 \%5bjunho 2012\%5d.pdf

Uphoff, N. (2000). Understanding social capital: Learning from the analysis and experience of participation. In P. Dasgupta \& I. Serageldin (Eds.), Social capital: A multifaceted perspective (pp. 215-252). Washington D.C.: The World Bank.

Vibhute, K. \& Aynalem, F. (2009). Legal research methods. Retrieved from https://chilot.files.wordpress.com/2011/06/legal-research-methods.pdf

Wintr, J. \& Koželuha, P. (2015). Teleological interpretation in Czech case Law. The Lawyer Quarterly, 5 (2), 133-149.

Zahra, A. \& McGehee, N.G. (2013). Volunteer tourism: A host community capital perspective. Annals of Tourism Research, 42, 22-45. doi: 10.1016/j.annals.2013.01.008

Zhao, W., Ritchie, J.R.B. \& Echtner, C.M. (2011). Social capital and tourism entrepreneurship. Annals of Tourism Research, 38 (4), 1570-1593. doi: 10.1016/j.annals.2011.02.006

TIAGO BORLIDO is currently enrolled in the Masters in Cultural Tourism at the University of Girona (Catalonia, Spain), following his Bachelor's Degree in Tourism at the Polytechnic Institute of Viana do Castelo (Portugal). His main research interests include creative and heritage tourism, sustainability in the tourism sector and dark tourism. Institutional address: Facultat de Turisme, Universitat de Girona Plaça Ferrater Mora, 1, 17071 Girona, Spain.

Submitted 4 May 2016

Accepted 10 September 2016 